\title{
Two new ant species (Formicidae: Dorylinae, Ponerinae) from New Caledonia
}

\author{
Thibault RAMAGE ${ }^{1}$, Corentin JOUAULT ${ }^{2}$, Alexander R. SCHMIDT ${ }^{3}$, \\ Leyla J. SEYFULLAH ${ }^{4} \&$ Vincent PERRICHOT ${ }^{5, *}$ \\ 19 Quartier de la Glacière, 29900 Concarneau, France. \\ 2,5 Univ Rennes, CNRS, Géosciences Rennes, UMR 6118, F-35000 Rennes, France. \\ ${ }^{3}$ Department of Geobiology, University of Göttingen, 37077 Göttingen, Germany. \\ ${ }^{4}$ Department of Palaeontology, University of Vienna, 1090 Vienna, Austria. \\ ${ }^{*}$ Corresponding author: vincent.perrichot@univ-rennes1.fr \\ ${ }^{1}$ Email: thibault.ramage@hotmail.fr \\ 2Email: jouaultc0@gmail.com \\ 33Email: alexander.schmidt@geo.uni-goettingen.de \\ ${ }^{4}$ Email: leyla.seyfullah@univie.ac.at

\footnotetext{
${ }^{1}$ urn:lsid:zoobank.org:author:8DE31F66-13BF-4516-A205-60F2EA39E3DD

${ }^{3}$ urn:1sid:zoobank.org:author:B8E42FD8-EEAD-405E-A44E-341886F22E6D

${ }^{5}$ urn:1sid:zoobank.org:author:BC661D50-24D5-4C74-B0C3-FB56E47ED306
} \\ ${ }^{2}$ urn:1sid:zoobank.org:author:1AAB69DA-A3D3-4218-AABF-5FD77CE36DCF \\ ${ }^{4}$ urn:1sid:zoobank.org:author:A1FA9DDD-CF0B-4ACC-9419-69B5B92E9B4F
}

\begin{abstract}
Two new species of ants (Hymenoptera: Formicidae) collected from New Caledonia are described and figured based on worker specimens: Leptogenys loarelae Ramage sp. nov. (Ponerinae, Ponerini) and Lioponera neocaledonica Jouault, Ramage \& Perrichot sp. nov. (Dorylinae, Cerapachyini). All specimens were collected from the South Province of Grande Terre. These two new species are primarily distinguished from the other New Caledonian relatives by the size and shape of petiole for $L$. loarelae Ramage sp. nov. and by the presence of dorsolateral margins on the mesosoma for L. neocaledonica Jouault, Ramage \& Perrichot sp. nov. Keys to New Caledonian Leptogenys and Lioponera are provided.
\end{abstract}

Keywords. Hymenoptera, Lioponera, Leptogenys, taxonomy, identification keys.

Ramage T., Jouault C., Schmidt A.R., Seyfullah L.J. \& Perrichot V. 2019. Two new ant species (Formicidae: Dorylinae, Ponerinae) from New Caledonia. European Journal of Taxonomy 589: 1-14.

https://doi.org/10.5852/ejt.2019.589

\section{Introduction}

New Caledonia, located in the southwest Pacific Ocean, is one of the 36 biodiversity hotspots identified worldwide by Conservation International (CEPF). It is an archipelago comprising the main island of 
Grande Terre, which is divided in length by a central mountain range, as well as the Belep Islands to the North, the Loyalty Islands to the East, the Isle of Pines to the South, the Chesterfield Islands and Bellona Reefs to the West, and few islets, all with a tropical marine climate. New Caledonia is considered a part of Zealandia, a continental fragment originating from the former Gondwana, with addition of terranes that accreted after the break up of Gondwana about 84 million years ago (Ma). The current New Caledonian biota displays a high diversity and endemism resulting from a complex geological and biogeographical history, with Palaeocene and Eocene submersions followed by colonization and radiations of taxa of both Gondwanan and Indo-Malayan origins in the last $37 \mathrm{Ma}$ (Grandcolas et al.2008; Nattier et al. 2017). However, there is still a debate on whether the archipelago was entirely or partially submerged, with the survival of archaic groups on ephemeral islands (Heads 2019).

Emery's (1883) pioneer work on the ant fauna of New Caledonia resulted in the description of seven species. He was soon followed by André (1889) and Forel (1894) who added two and three species, respectively, and he himself described 37 additional species, most of them endemic to the archipelago (Emery 1914). Since then, most of the species described from New Caledonia were part of regional or global generic revisions (Viehmeyer 1924; Brown 1958; Wilson 1958; Brown \& Kempf 1960; Bolton 2000; Baroni Urbani \& de Andrade 2003; Lucky \& Ward 2010; Heterick \& Shattuck 2011; Shattuck 2011; Taylor 2018; Sparks et al. 2019), with, however, some works focusing on New Caledonia (Brown 1948; Wilson 1957; Ward 1984). Wheeler (1935), Taylor (1987) and Jennings et al. (2013) also produced local ant checklists. To date, the New Caledonian ant fauna comprises 134 species and subspecies, 55\% of which apparently endemic (Antweb 2019). However, recent studies (Berman 2012; Berman \& Andersen 2012; Berman et al. 2013a, 2013b; Antwiki 2019) show many species remaining to be described.

Here, we report new species of Leptogenys Roger, 1861 and Lioponera Mayr, 1879, two genera of epigaeic predatory ants collected from mountain forests of Grande Terre. We also provide identification keys for the New Caledonian species to facilitate future work on these two genera.

The genus Leptogenys is found throughout the world's tropical and subtropical zones with over 300 known extant species (Bolton 2019). Molecular phylogenetic analyses showed that Leptogenys is a monophyletic taxon within the Odontomachus genus group (Schmidt 2013). The diversification of this group probably occurred in Africa between 40 and $30 \mathrm{Ma}$ and had an explosive nature (Schmidt 2013). Leptogenys is the most species-rich genus within the subfamily Ponerinae and its members display a diversity of foraging strategies and reproductive systems (Schmidt \& Shattuck 2014). Important taxonomic work has been done on this genus: Lattke (2011) revised the New World fauna, Rakotonirina \& Fisher (2014) the Malagasy fauna, Xu et al. (2015) the Oriental species and Arimoto (2017) the modiglianii species group. Keys for the Indian fauna are found in Bharti \& Wachkoo (2013) and for Leptogenys of the Arabian Peninsula in Sharaf et al. (2017). Most species of Leptogenys are known as specialized predators of isopods (Dejean \& Evraerts 1997; Dejean 1997). The presence of ergatoid gynes and gamergates has been established in most of the studied species, but flying queens were also found in two Asian species (Peeters 2012). Ergatoid queens and gamergates is an alternative to breedings with winged breeders. Indeed, it guarantees a strategy of rapid and less expensive reproduction by the fission of colonies. However, it is obvious that dispersal capabilities, particularly at long distances, are lost in the fission of colonies (Schmidt 2013). Reproductive methods of this type remain unclear since winged gynes have been reported for two Asian species (Ito \& Okawahara 2000).

The genus Lioponera was synonymized with Cerapachys Smith, 1857 by Brown (1975), but revived from synonymy by Borowiec (2016). Lioponera is found in Africa, Asia and Oceania, mainly in tropical and subtropical zones, and is currently known to comprise 74 species (Antweb 2019). Australia hosts 
a major radiation of Lioponera, with 43 reported species. Lioponera is sister to the clade comprising Lividopone Bolton \& Fisher, 2016, Parasyscia Emery, 1882 and Zasphinctus Wheeler, 1918 (Brady et al. 2014). Phylogenetic studies suggest that the genus may have originated in Africa and later spread to the Indomalayan and Australasian regions (Borowiec 2019). Lioponera occurs only in the Old World and all species observed thus far prey on other ants.

\section{Material and methods}

\section{Taxon sampling}

The material examined in this study is based on sampling carried out in the South Province of Grande Terre. One specimen was collected in 2010 by Maïa Berman during her PhD on ant ecology (Fire project) at Charles Darwin University (Australia) (Berman 2012). All other specimens were collected by VP in 2011, during experimental fieldwork for actuo-paleontological studies of resin-producing araucarian forests of New Caledonia (e.g., Beimforde et al. 2017). Both samplings were conducted with permission obtained from the Direction de l'Environnement de la Province Sud (permit 1357-2010/ARR/DENV to Alan Andersen/Maïa Berman and 17778/DENV/SCB to VP).

\section{Repositories}

Collections are referred to by the following acronyms:

ANIC $=$ Australian National Insect Collection, Canberra
CASENT $=$ California Academy of Sciences, Entomology, San Francisco, USA
MNHN $=$ Muséum national d'histoire naturelle, Paris, France

\section{Specimen examination}

The taxonomic analysis was conducted using an AMSCOPE stereo microscope equipped with a micrometer, at magnification $40 \times$. Series of photographs were taken at different focal planes using a Canon EOS 60D camera mounted on a Nikon SMZ 1500, stacked using CombineZP or Helicon Focus and processed with Adobe Photoshop.

\section{Abbreviations}

Morphological terminology for measurements and indices includes the following abbreviations:

$\mathrm{DPW}=$ Dorsal petiole width: maximum width of the petiole in dorsal view

$\mathrm{ED}=$ Eye diameter: maximum length of eye as measured normally in oblique view of the head to show full surface of eye

$\mathrm{HL}=$ Head length: maximum length of head in dorsal view, measured in straight line from the anterior-most point of the clypeus flank to the midpoint of the frontovertexal margin

HW $=$ Head width: maximum width of head in dorsal view

$\mathrm{MH}=$ Mesosoma height: in side view, maximum height measured from the lowermost point of the mesopleuron (in front of middle coxa) to the dorsal edge of the mesosoma

MSL $=$ Mesosoma length: length of mesosoma in lateral view, the anterior surface of the pronotum proper (excluding the collar) to the posterior extension of the propodeal lobes

$\mathrm{PH}=$ Petiole height: height of the petiole measured in lateral view from the apex of the ventral (subpetiolar) process vertically to a line intersecting the dorsalmost point of the node

$\mathrm{PL}=$ Petiole length: length of the petiole from the anterior process to the posteriormost point of the tergite, where it surrounds the gastral articulation

$\mathrm{PW}=$ Pronotal width: maximum width of pronotum in dorsal view

$\mathrm{SL}=$ Scape length: maximum length of the scape excluding the basal neck and condyle

$\mathrm{T} 1 \mathrm{~L}=$ first abdominal tergite length, maximum length in dorsal view 
$\mathrm{T} 1 \mathrm{~W}=$ first abdominal tergite width, maximum width in dorsal view

$\mathrm{T} 2 \mathrm{~L}=$ second abdominal tergite length, maximum length in dorsal view

$\mathrm{T} 2 \mathrm{~W}=$ second abdominal tergite width, maximum width in dorsal view

$\mathrm{TL}=$ total length

\title{
Indices
}

$$
\begin{aligned}
& \mathrm{CI}=\text { Cephalic index: } \mathrm{HW} / \mathrm{HL} \times 100 \\
& \mathrm{DPI}=\text { Dorsal petiole index: } \mathrm{DPW} / \mathrm{PL} \times 100 \\
& \mathrm{LPI}=\text { Lateral petiole index: } \mathrm{PH} / \mathrm{PL} \times 100 \\
& \mathrm{SI}=\text { Scape index: } \mathrm{SL} / \mathrm{HW} \times 100
\end{aligned}
$$

\section{Results}

\author{
Class Insecta Linnaeus, 1758 \\ Order Hymenoptera Linnaeus, 1758 \\ Family Formicidae Latreille, 1809 \\ Subfamily Ponerinae Lepeletier de Saint-Fargeau, 1835 \\ Genus Leptogenys Roger, 1861 \\ Leptogenys loarelae Ramage sp. nov. \\ urn:1sid:zoobank.org:act:819E8C18-56F7-4CB5-AE07-00B5406D924A
}

Fig. 1

\section{Diagnosis}

Leptogenys loarelae Ramage sp. nov. can be distinguished from other New Caledonia species of Leptogenys by the unique combination of the following features: integument smooth and shining, mostly black colored with blueish reflection; third antennal segment markedly elongate, more than twice the length of pedicel; mandible elongate, triangular; petiole elongate, nearly three times longer than broad in dorsal view.

\section{Etymology}

The specific epithet refers to the first name of Thibault Ramage's daughter, Loarel. The species epithet is to be treated as a noun in the genitive case.

\section{Type material}

\section{Holotype}

NEW CALEDONIA - wingless + ; Grande Terre, Province Sud, Sarraméa, Plateau de Dogny trail; 21 ${ }^{\circ} 37^{\prime} 10.7^{\prime \prime} \mathrm{S}, 165^{\circ} 52^{\prime} 31.9^{\prime \prime} \mathrm{E} ; 897 \mathrm{~m} ; 16$ Nov. 2011; V. Perrichot leg. [VP209]; mixed mountain forest, hand picking on ground; MNHN.

\section{Description}

\section{Worker holotype}

MEAsurements (in mm). TL 11.5; HL 2.06; HW 1.3; SL 2.56; ED 0.5; PW 1.16; MSL 3.65; PL 1.83; PH 0.8; DPW 0.63; CI 62.9; SI 197.4; LPI 43.6; DPI 34.5.

HEAD. Elongate, sub-trapezoidal, lateral sides diverging anteriorly (Fig. 1B); lateral margin barely convex; posterior margin weakly concave medially, posterior lateral corners rounded. Clypeus triangular, with blunt apex and sligthly concave side margins. In full-face view, eye large, oval, maximum diameter greater than twice the maximum width of scape; placed at head midline. Antennae with scape long and slightly enlarged medially, surpassing posterior margin of head by its $2 / 5^{\text {th}}$; funicular segments elongate; 


\section{RAMAGE T. et al, New ant species from New Caledonia}

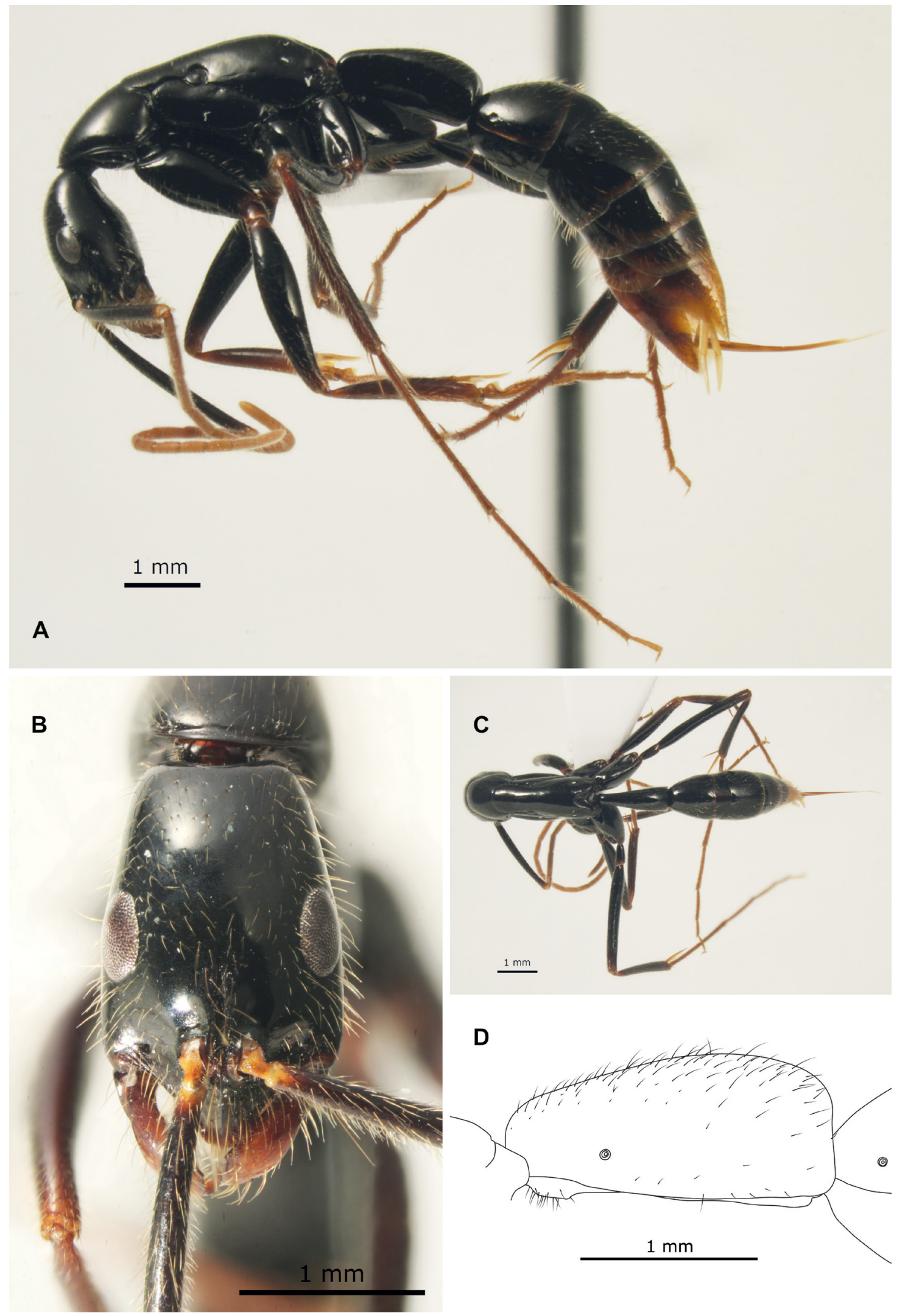

Fig. 1. Leptogenys loarelae Ramage sp. nov., holotype, ${ }_{+}(\mathrm{MNHN})$. A. Body in profile view. B. Head in full-face view. C. Body in dorsal view. D. Reconstruction of petiole in left profile view. 
third antennal segment markedly elongate, more than twice the length of the second. Mandible triangular, elongate, shorter than head width; masticatory margin edentate.

Mesosoma (Fig. 1A, C). Elongate, compressed laterally, widest at pronotum; mesosomal dorsal surface in profile slightly convex. In dorsal view, mesonotum as long as broad. Propodeal spiracle slit-like. Petiole (Fig. 1A, C-D) elongate, nearly three times as long as broad, trapezoidal, widest at apex; dorsal surface of petiolar node convex, posterior surface slightly concave, anterodorsal and posterodorsal corners angular. Subpetiolar process small, trapezoidal; located beneath anterior $1 / 5^{\text {th }}$ of the petiole (Fig. 1D). Gaster elongate.

INTEGUMENT. Smooth and shining, very finely and sparsely punctate; mostly black with blueish reflection, except mandibles, antennal radicel and funicular articles, tarsomeres and hypopygium and pygidium reddish brown. Dorsum of body covered by erect and suberect yellow setae; setae longer on head, scape, pronotum, procoxa and gaster, but shorter on remaining body.

Key to the Leptogenys species (workers) of New Caledonia (modified from Wilson 1958)

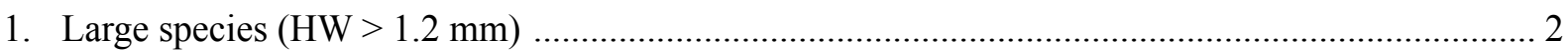

- Small species $(\mathrm{HW} \leq 1.2 \mathrm{~mm})$

2. Mandibles exceptionally long, their length measured from insertion to tip exceeding the head width (Fig. 2A)

Leptogenys rouxi Emery, 1914

- Mandibles shorter, their length much less than the head width (Fig. 1B)

Leptogenys loarelae Ramage sp. nov.

3. Head entirely covered by coarse punctures (Fig. 2C)

Leptogenys punctata Emery, 1914

- Head entirely smooth and shining (Fig. 2B)

4. Larger species, head width $\geq 0.9 \mathrm{~mm}$; in dorsal view, posterior corners of petiolar node forming distinct angles of $45-50^{\circ}$ (Fig. 3A)

Leptogenys acutangula Emery, 1914

- Smaller species, head width not exceeding $0.75 \mathrm{~mm}$; in dorsal view, posterior corners of petiolar node thick and broadly rounded (Fig. 3B) Leptogenys sagaris Wilson, 1958
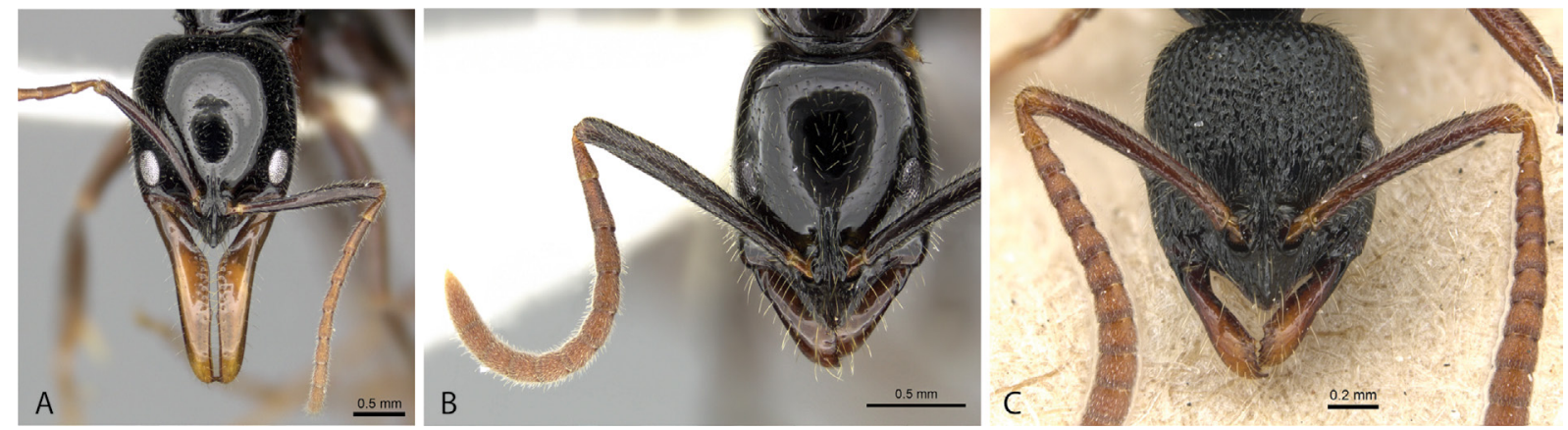

Fig. 2. Comparison of head, in full-face view, of species of Leptogenys of New Caledonia. A. L. rouxi Emery, 1914 (CASENT0270571). B. L. acutangula Emery, 1914 (CASENT0270535). C. L. punctata Emery, 1914 (CASENT0903948). Images: A-B by Estella Ortega, C by Will Ericson. 


\section{Subfamily Dorylinae Leach, 1815}

Genus Lioponera Mayr, 1879

Lioponera neocaledonica Jouault, Ramage \& Perrichot sp. nov.

urn:1sid:zoobank.org:act:7612551C-6C0A-4931-9D06-8FC8062DB5E3

Figs 4, 5B

\section{Diagnosis}

Lioponera neocaledonica Jouault, Ramage \& Perrichot sp. nov. is mostly characterized by the combination of the following features: mesosoma dorsolaterally conspicuously marginate, propodeal declivity without dorsal margin; posterolateral corners of petiole not projected into spines. The two latter features easily serve to distinguish $L$. neocaledonica Jouault, Ramage \& Perrichot sp. nov. from the other New Caledonian species L. cohici (Wilson, 1957) (Fig. 5A) and L. dumbletoni (Wilson, 1957) (Fig. 5C).

\section{Etymology}

The specific epithet refers to New Caledonia where the species was discovered.

\section{Type material}

\section{Holotype}

NEW CALEDONIA - wingless $q$; Grande Terre, Province Sud, Sarraméa, Plateau de Dogny trail; $21^{\circ} 37^{\prime} 31^{\prime \prime}$ S, 165 52'5" E; 441 m; 16 Nov. 2011; V. Perrichot leg. [VP188]; mixed mountain forest, hand picking on ground; MNHN.

\section{Paratypes}

NEW CALEDONIA • 2 wingless 9 ; $;$ same collection data as for holotype; MNHN $\bullet 1$ wingless $O$;

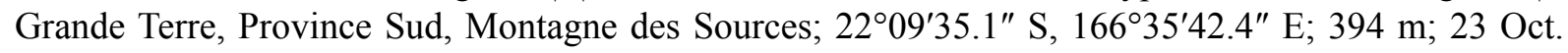
2010; M. Berman leg. [CSIRONC0055]; ANIC 32-146088.

\section{Description (holotype)}

MEASUREMENTS (in mm; holotype in brackets). TL 4.12-4.15 (4.15); HL 0.8-0.85 (0.85); HW 0.7-0.77 (0.77); SL 0.45-0.52 (0.52); ED 0.2-0.25 (0.2); PW 0.65-0.72 (0.7) ; MH 0.52-0.62 (0.62); MSL 1.0251.12 (1.12); PL 0.45-0.55 (0.55); PH 0.4-0.42 (0.42); DPW 0.67-0.7 (0.7); T1W 0.65-0.77 (0.77);
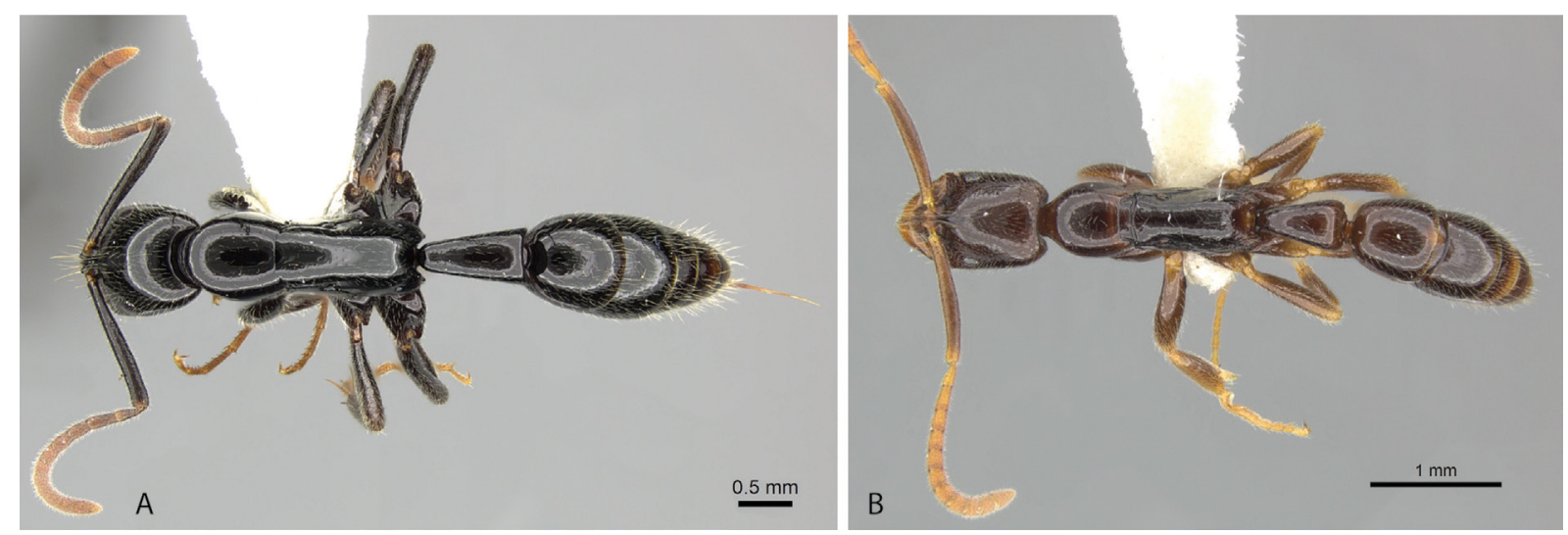

Fig. 3. Comparison of the body in dorsal view of Leptogenys species of New Caledonia. A. L. acutangula Emery, 1914 (CASENT0270535). B. L. sagaris Wilson, 1958 (CASENT0270576). Images: A by Estella Ortega, B by Ryan Perry. 
T1L 0.5-0.62 (0.62); T2W 0.75-0.82 (0.82); T2L 0.6-0.65 (0.65). Indices: CI 84-91 (91); SI 64-69 (67); LPI 76-94 (77); DPI 127-150 (127).

HEAD (Fig. 4C). Sub-rectangular, slightly longer than broad, widest above midline of head; lateral sides slightly convex; vertexal margin slightly concave, posterior lateral corners slightly rounded. Parafrontal ridges angular. Compound eyes of medium size, situated below midline of head. Mandible elongate, triangular, masticatory margin with 10 small teeth. Antennae with scape short and clavate, reaching up to two fifth of posterior margin of head.

Mesosoma (Fig. 4A-B, D). Stout, roughly rectangular in dorsal view, with conspicuous dorsolateral margins, the margins notched around promesonotal junction; mesosomal dorsal surface convex, propodeal declivity without dorsal margin.

Metasoma. Petiole (Fig. 4A-B, E) broader than long, slightly trapezoidal, widest at two thirds of length; anterior petiolar surface concave; dorsal petiolar surface convex, with dorsolateral margins well developed and convex, without anterodorsal and posterodorsal margins; posterior petiolar surface slightly convex; anterodorsal and posterodorsal corners angular. Subpetiolar process small, triangular, with stout acute somewhat hooked apex; fenestra absent. Gaster elongate (Fig. 4A-B), with distinct girdling constriction (cinctus) between abdominal segments III and IV. Abdominal segment II trapezoidal, slightly broader than long, widest at one third of length; dorsal surface slightly convex; dorsolateral margins well developed and strongly convex; anterodorsal margin sinuate; anterodorsal corner broadly rounded; posterolateral corner angular. Sting exerted, upcurved.

IntEgument. Mostly black except last two funicular articles, tarsomeres, and posterior margins of abdominal segments IV to V brown. Body finely and sparsely punctate; reticulation present on sides of the mesosoma, becoming shallower from propleura to propodeum; cinctus, abdominal segment IV, base of abdominal segments V, VI and pygidium transversally, finely and shallowly striate. Body covered with suberect hairs; scape with abundant appressed hairs; tibiae with scattered decumbent hairs; tarsi with abundant decumbent to appressed hairs; declivous face of propodeum with short, dense and appressed hairs.

\section{Remarks}

The potential presence of ergatogynes in Lioponera (Wilson 1957; Borowiec 2016) prevents assignment of the present specimens to workers or ergatogynes.

Key to the species of Lioponera of New Caledonia (modified from Wilson 1957)

1. Large species (HW $>1.1 \mathrm{~mm}$ ), with long scapes reaching nearly to posterior corners of head; mesosomal dorsolateral margins absent ..Lioponera dumbletoni (Wilson, 1957)

- Small species $(\mathrm{HW}<1.1 \mathrm{~mm}$ ), scapes barely surpassing eyes; mesosomal dorsolateral margins present (Fig. 4A, D)

2. Mesosomal posterodorsal margin present; posterolateral corners of petiole projected into spines (Fig. 5A)

Lioponera cohici (Wilson, 1957)

- Mesosomal posterodorsal margin absent (Fig. 4D); posterolateral corners of petiole not projected into spines (Fig. 5B) Lioponera neocaledonica Jouault, Ramage \& Perrichot sp. nov.

\section{Discussion}

The new species described above were mostly collected along the trail from Sarraméa to the Plateau de Dogny, except the specimen collected from the Montagne des Sources. Both localities are situated in the central mountain range of New Caledonia and display humid forests growing on an ultramafic 

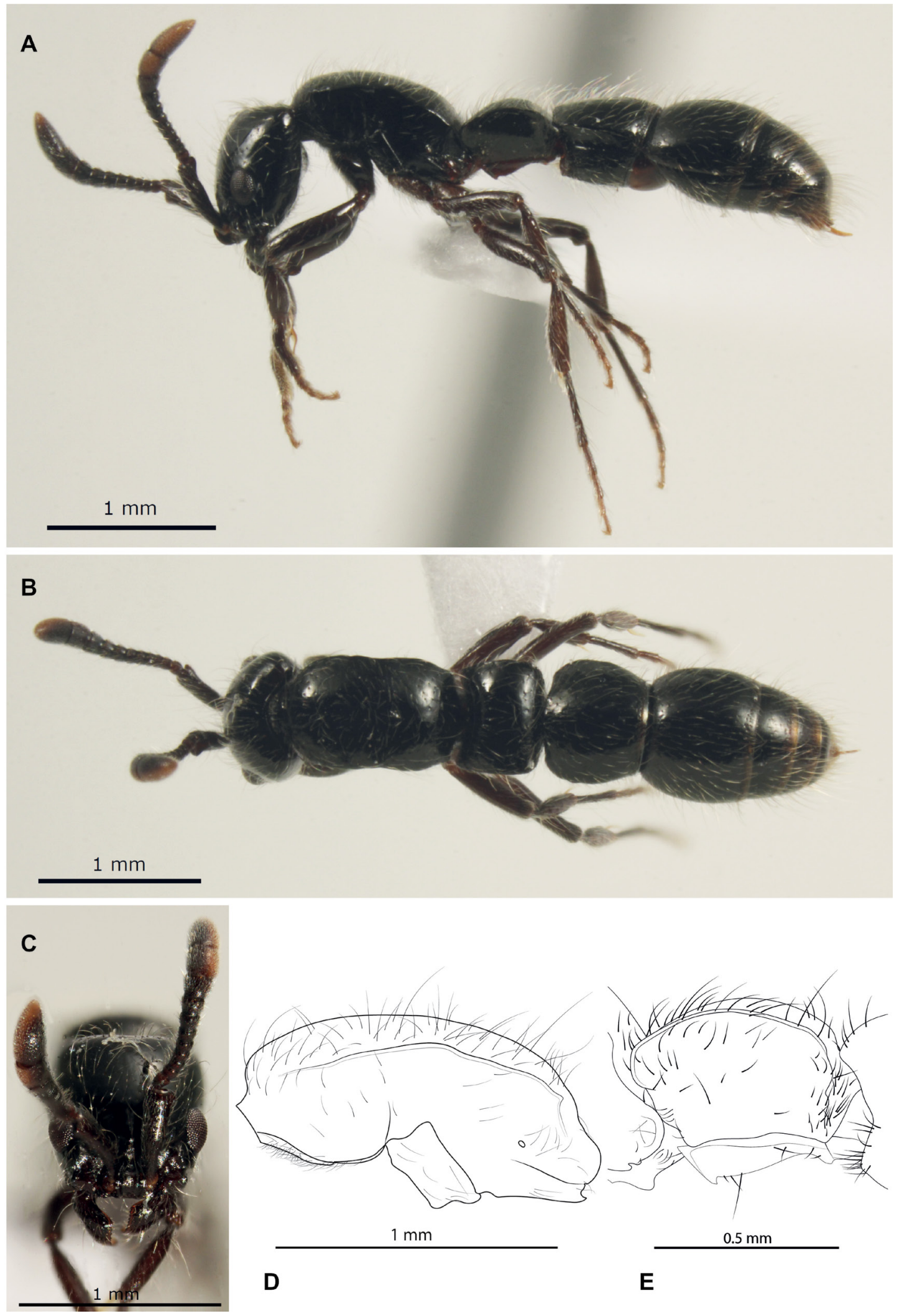

D

E

Fig. 4. Lioponera neocaledonica Jouault, Ramage \& Perrichot sp. nov., holotype, $q$ (MNHN). A. Body in profile view. B. Body in dorsal view. C. Head in full-face view. D. Reconstruction of mesosoma in left profile view. E. Reconstruction of petiole in left profile view. 
ground. The trail to Plateau de Dogny shows three different plant zonations along a gradient of elevation from 20 to $1030 \mathrm{~m}$. There, Lioponera was collected on the forest soil at an elevation of $441 \mathrm{~m}$, which corresponds to a mixed humid forest supporting abundant shrubs of the remarkable, endemic basal angiosperm species Amborella trichopoda Baill. (Amborellaceae) as well as ferns of the Marattiaceae, namely Ptisana rolandiprincipis (Rosenst.) Christenh. (Fig. 6). Leptogenys was collected on the soil at an elevation of $897 \mathrm{~m}$, which corresponds to a humid forest harbouring plenty of trees of the likewise endemic Austrotaxus spicata Compton (Taxaceae).

Specialized predation on oniscoid isopods seems to dominate in the genus Leptogenys, although there have been reports on other preys such as earwigs or termites (Bolton 1975; Steghaus-Kovac \& Maschwitz 1993; Dejean 1997; Dejean \& Evraerts 1997). Some Oriental species have an army ant lifestyle and are generalists (Witte \& Maschwitz 2000). Unfortunately, no data exist on the diet of the New Caledonian

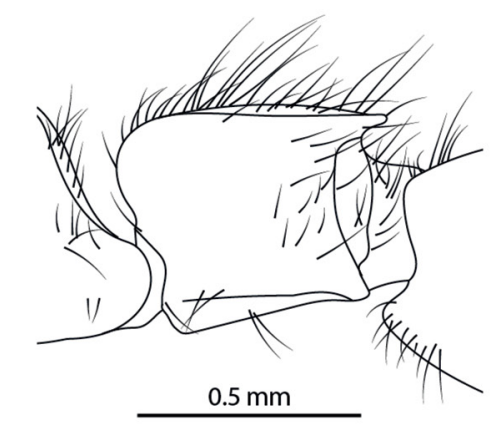

A

Fig. 5. Comparison of petioles in Lioponera species of New Caledonia. A. L. cohici (Wilson, 1957) (CASENT0249291). B. L. neocaledonica Jouault, Ramage \& Perrichot sp. nov. (MNHN). C. Lioponera dumbletoni (Wilson, 1957) (CASENT0249292).
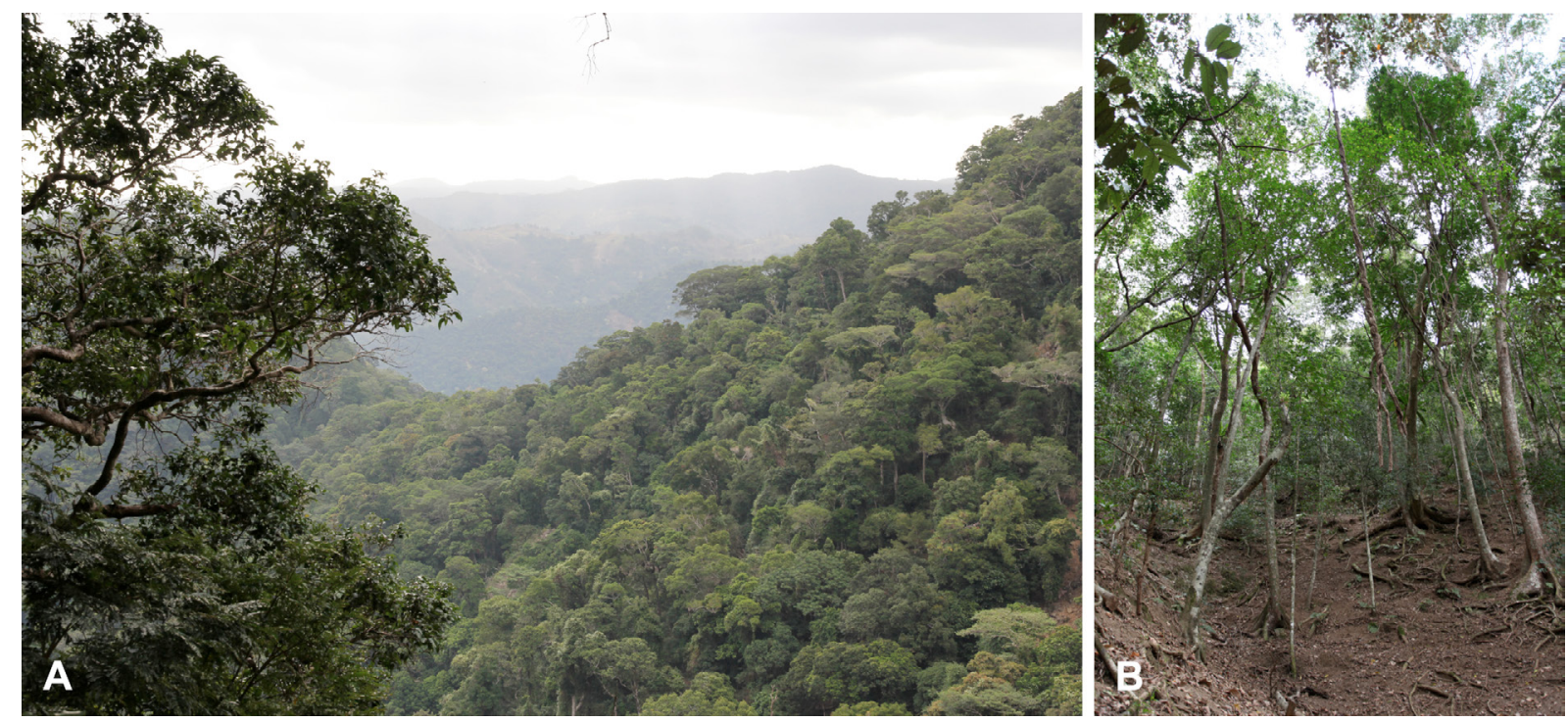

Fig. 6. Type locality of the new species. A. General view from the trail to Plateau de Dogny (Sarraméa, New Caledonia). B. Habitat of Lioponera neocaledonica Jouault, Ramage \& Perrichot sp. nov. 
Leptogenys. Leptogenys loarelae Ramage sp. nov., together with L. acutangula and L. sagaris from New Caledonia, shares affinities with the Leptogenys fauna of Australia and Papua New Guinea. Leptogenys keysseri Viehmeyer, 1914, from Papua New Guinea, is largely similar to L. loarelae Ramage sp. nov., but its petiole is much more narrowed anteriorly.

Species of Lioponera are predators of other ants, like most other Dorylinae (Borowiec 2016). At least one species in Australia exhibits a preference in preying on Pheidole Westwood, 1839 (Hölldobler 1982), and in Japan one species seems to prey on Monomorium Mayr, 1855 (Idogawa \& Dobata 2018). In New Caledonia, Wilson (1957) observed Lioponera cohici raiding colonies of a species of Pheidole, while he found remains of an undetermined species of Lordomyrma Emery, 1897 in a nest of Lioponera dumbletoni. Data on the diet of Lioponera neocaledonica Jouault, Ramage \& Perrichot sp. nov. are missing.

Based on these two new discoveries, it is certain that important inventorial and taxonomic work remains to be done in New Caledonia. This first publication will serve as a basis for future work on the myrmecofauna of New Caledonia.

\section{Acknowledgements}

We are grateful to Alan Andersen and Maïa Berman (Charles Darwin University) for access to the ANIC specimen; to Jouko Rikkinen and Christina Beimforde who took part in the field experiments and sampling with ARS, LJS and VP; to Antoine Mantilleri (Terrestrial Arthropod Collections Management Unit, MNHN) for access to the photo room; and to David Yeates, Federica Turco and Robyn Meier (ANIC) for providing specimen's accession numbers. Fieldwork and collection in southern New Caledonia were kindly permitted by the Direction de l'Environnement (Province Sud), permits 17778/ DENV/SCB delivered in November 2011 to VP and 1357-2010/ARR/DENV delivered in 2010 to Alan Andersen/Maïa Berman. Partial support for fieldwork was provided to VP by grant OSUR (Univ. Rennes 1) from program AO1.P4 of 2011. We thank Marek Borowiec and an anonymous reviewer for helpful comments and suggestions.

\section{References}

André E. 1889. Hyménoptères nouveaux appartenant au groupe des Formicides. Revue d'Entomologie 8: 217-231.

Antweb. 2019. New Caledonia. Available from

https://www.antweb.org/country.do?name=New+Caledonia [accessed 27 May 2019].

Antwiki. 2019. Ant Diversity of New Caledonia. Available from

http://www.antwiki.org/wiki/Ant_Diversity_of_New_Caledonia [accessed 27 May 2019].

Arimoto K. 2017. Taxonomy of the Leptogenys modiglianii species group from southeast Asia (Hymenoptera, Formicidae, Ponerinae). ZooKeys 651: 79-106.

https://doi.org/10.3897/zookeys.651.10336

Baroni Urbani C. \& de Andrade M.L. 2003. The ant genus Proceratium in the extant and fossil record (Hymenoptera: Formicidae). Museo Regionale di Scienze Naturali, Monografie 36: 1-492.

Beimforde C., Seyfullah L.J., Perrichot V., Schmidt K., Rikkinen J. \& Schmidt A.R. 2017. Resin exudation and resinicolous communities on Araucaria humboldtensis in New Caledonia. ArthropodPlant Interactions 11: 495-505. https://doi.org/10.1007/s11829-016-9475-3

Berman M. 2012. Impacts of Anthropogenic Fires and Invasive Ants on Native Ant Diversity in New Caledonia: from Genes to Communities. PhD thesis, Université Montpellier 2, France and Charles Darwin University, Australia. 
Berman M. \& Andersen A.N. 2012. New Caledonia has a depauperate subterranean ant fauna, despite spectacular radiations above ground. Biodiversity and Conservation 21: 2489-2497.

https://doi.org/10.1007/s10531-012-0309-z

Berman M., Andersen A.N., Hély C. \& Gaucherel C. 2013a. Overview of the distribution, habitat association and impact of exotic ants on native ant communities in New Caledonia. PLOS ONE 8 (6): e67245. https://doi.org/10.1371/journal.pone.0067245

Berman M., Andersen A.N. \& Ibanez T. 2013b. Invasive ants as back-seat drivers of native ant diversity decline in New Caledonia. Biological Invasions 15: 2311-2331.

https://doi.org/10.1007/s10530-013-0455-6

Bharti H. \& Wachkoo A.A. 2013. Two new species of the ant genus Leptogenys (Hymenoptera: Formicidae) from India, with description of a plesiomorphic ergatogyne. Asian Myrmecology 5: 11-19.

Bolton B. 1975. A revision of the ant genus Leptogenys Roger (Hymenoptera: Formicidae) in the Ethiopian region with a review of the Malagasy species. Bulletin of the British Museum (Natural History) - Entomology 31: 235-305. https://doi.org/10.5962/bhl.part.29487

Bolton B. 2000. The ant tribe Dacetini. Memoirs of the American Entomological Institute 65: 1-1028.

Bolton B. 2019. An Online Catalog of the Ants of the World. Available from http://www.antcat.org/ [accessed 27 May 2019].

Borowiec M.L. 2016. Generic revision of the ant subfamily Dorylinae (Hymenoptera, Formicidae). ZooKeys 608: 1-280. https://doi.org/10.3897/zookeys.608.9427

Borowiec M.L. 2019. Convergent evolution of the army ant syndrome and congruence in big-data phylogenetics. Systematic Biology 68: 642-656. https://doi.org/10.1093/sysbio/syy088

Brady S.G., Fisher B.L., Schultz T.R. \& Ward P.S. 2014. The rise of army ants and their relatives: diversification of specialized predatory doryline ants. BMC Evolutionary Biology 14: 1-14.

https://doi.org/10.1186/1471-2148-14-93

Brown W.L. 1948. A new Discothyrea from New Caledonia (Hymenoptera: Formicidae). Psyche 55: 38-40. https://doi.org/10.1155/1948/36948

Brown W.L. 1958. Contributions toward a reclassification of the Formicidae. II. Tribe Ectatommini (Hymenoptera). Bulletin of the Museum of Comparative Zoology at Harvard College 118: 173-362.

Brown W.L. 1975. Contributions toward a reclassification of the Formicidae. V. Ponerinae, tribes Platythyreini, Cerapachyini, Cylindromyrmecini, Acanthostichini, and Aenictogitini. Search Agriculture (Cornell University, Ithaca) 5(1): 1-115.

Brown W.L. \& Kempf W.W. 1960. A world revision of the ant tribe Basicerotini. Studia Entomologica 3: $161-250$.

CEPF. Explore the Biodiversity Hotspots.

Available from https://www.cepf.net/our-work/biodiversity-hotspots [accessed 27 May 2019].

Dejean A. 1997. Distribution of colonies and prey specialization in the ponerine ant genus Leptogenys (Hymenoptera: Formicidae). Sociobiology 29: 293-300.

Dejean A. \& Evraerts C. 1997. Predatory behavior in the genus Leptogenys: a comparative study. Journal of Insect Behavior 10: 177-191. https://doi.org/10.1007/BF02765551

Emery C. 1883. Alcune formiche della Nuova Caledonia. Bollettino della Società Entomologica Italiana 15: $145-151$. 
Emery C. 1914. Les fourmis de la Nouvelle-Calédonie et des îles Loyalty. Nova Caledonia. Forschungen in Neu-Caledonien und auf den Loyalty-Inseln. Recherches scientifiques en Nouvelle-Calédonie et aux iles Loyalty. A. Zoologie 1: 393-437. https://doi.org/10.5962/bhl.title.6790

Forel A. 1894. Quelques fourmis de Madagascar (récoltées par M. le Dr. Voltzkow); de Nouvelle Zélande (récoltées par M.W.W. Smith); de Nouvelle Calédonie (récoltées par M. Sommer); de Queensland (Australie) (récoltées par M. Wiederkehr); et de Perth (Australie occidentale) (récoltées par M. Chase). Annales de la Société entomologique de Belgique 38: 226-237.

Grandcolas P., Murienne J., Robillard T., Desutter-Grandcolas L., Jourdan H., Guilbert E. \& Deharveng L. 2008. New Caledonia: a very old Darwinian island? Philosophical Transactions of the Royal Society B 363: 3309-3317. https://doi.org/10.1098/rstb.2008.0122

Heads M. 2019. Recent advances in New Caledonian biogeography. Biological Reviews 94: 957-980. https://doi.org/10.1111/brv.12485

Heterick B.E. \& Shattuck S.O. 2011. Revision of the ant genus Iridomyrmex (Hymenoptera: Formicidae). Zootaxa 2845: 1-175.

Hölldobler B. 1982. Communication, raiding behavior and prey storage in Cerapachys (Hymenoptera: Formicidae). Psyche 89: 3-23. https://doi.org/10.1155/1982/28390

Idogawa N. \& Dobata S. 2018. Colony structure and life history of Lioponera daikoku (Formicidae: Dorylinae). Asian Myrmecology 10: e010006. https://doi.org/10.20362/am.010006

Ito F. \& Ohkawara K. 2000. Production and behavior of ergatoid queens in two species of the Indonesian ponerine ant genus Leptogenys (diminuta-group) (Hymenoptera: Formicidae). Annals of the Entomological Society of America 93: 869-873.

https://doi.org/10.1603/0013-8746(2000)093[0869:PABOEQ]2.0.CO;2

Jennings J.T., Krogmann L. \& Burwell C. 2013. Review of the Hymenopteran fauna of New-Caledonia with a checklist of species. Zootaxa 3736: 1-53. https://doi.org/10.11646/zootaxa.3736.1.1

Lattke J.E. 2011. Revision of the New World species of the genus Leptogenys Roger (Insecta: Hymenoptera: Formicidae: Ponerinae). Arthropod Systematics \& Phylogeny 69: 127-264.

Lucky A. \& Ward P.S. 2010. Taxonomic revision of the ant genus Leptomyrmex Mayr (Hymenoptera: Formicidae). Zootaxa 2688: 1-67. https://doi.org/10.11646/zootaxa.2688.1.1

Nattier R., Pellens R., Robillard T., Jourdan H., Legendre F., Caesar M., Nel A. \& Grandcolas P. 2017. Updating the phylogenetic dating of New Caledonian biodiversity with a meta-analysis of the available evidence. Scientific Reports 7: 3705. https://doi.org/10.1038/s41598-017-02964-x

Peeters C. 2012. Convergent evolution of wingless reproductives across all subfamilies of ants, and sporadic loss of winged queens (Hymenoptera: Formicidae). Myrmecological News 16: 75-91.

Rakotonirina J.C. \& Fisher B.L. 2014. Revision of the Malagasy ponerine ants of the genus Leptogenys Roger (Hymenoptera: Formicidae). Zootaxa 3836: 1-163. https://doi.org/10.11646/zootaxa.3836.1.1

Schmidt C. 2013. Molecular phylogenetics of ponerine ants (Hymenoptera: Formicidae: Ponerinae). Zootaxa 3647: 201-250. https://doi.org/10.11646/zootaxa.3647.2.1

Schmidt C.A. \& Shattuck S.O. 2014. The higher classification of the ant subfamily Ponerinae (Hymenoptera: Formicidae), with a review of ponerine ecology and behavior. Zootaxa 3817: 1-242. https://doi.org/10.11646/zootaxa.3817.1.1

Sharaf M.R., Akbar S.A., Al Dhafer H.M. \& Aldawood S.A. 2017. A new ant species of the Leptogenys sulcinoda-group (Hymenoptera: Formicidae) from Saudi Arabia. Zoology in the Middle East 7140: 1-8. https://doi.org/10.1080/09397140.2017.1292645 
Shattuck S.O. 2011. Revision of the ant genus Calyptomyrmex (Hymenoptera: Formicidae) in Southeast Asia and Oceania. Zootaxa 2743: 1-26. https://doi.org/10.11646/zootaxa.2743.1.1

Sparks K.S., Andersen A.N. \& Austin A.D. 2019. A multi-gene phylogeny of Australian Monomorium Mayr (Hymenoptera: Formicidae) results in reinterpretation of the genus and resurrection of Chelaner Emery. Invertebrate Systematics 33: 225-236. https://doi.org/10.1071/IS16080

Steghaus-Kovac S. \& Maschwitz U. 1993. Predation on earwigs: a novel diet specialization within the genus Leptogenys (Formicidae: Ponerinae). Insectes Sociaux 40: 337-340.

https://doi.org/10.1007/BF01242370

Taylor R.W. 1987. A checklist of the ants of Australia, New Caledonia and New Zealand (Hymenoptera: Formicidae). CSIRO Australia, Division of Entomology Report 41: 1-92.

Taylor R.W. 2018. New species of the ant genus Metapone Forel, 1911: first records from New Caledonia and Vanuatu (Hymenoptera: Formicidae). Myrmecological News 26: 97-100.

https://doi.org/10.25849/myrmecol.news_026:097

Viehmeyer H. 1924. Formiciden der australischen Faunenregion. Entomologische Mitteilungen 13: 219-229.

Ward P.S. 1984. A revision of the ant genus Rhytidoponera (Hymenoptera: Formicidae) in New Caledonia. Australian Journal of Zoology 32: 131-175. https://doi.org/10.1071/ZO9840131

Wheeler W.M. 1935. Check list of the ants of Oceania. Occasional Papers of the Bernice Pauahi Bishop Museum 11 (11): 1-56.

Witte V. \& Maschwitz U. 2000. Raiding and emigration dynamics in the ponerine army ant Leptogenys distinguenda (Hymenoptera, Formicidae). Insectes Sociaux 47: 76-83.

https://doi.org/10.1007/s000400050012

Wilson E.O. 1957. The discovery of cerapachyine ants on New Caledonia, with the description of new species of Phyracaces and Sphinctomyrmex. Breviora 74: 1-9.

Wilson E.O. 1958. Studies on the ant fauna of Melanesia. I. The tribe Leptogenyini. II. The tribes Amblyoponini and Platythyreini. Bulletin of the Museum of Comparative Zoology 118: 101-153.

Xu Z.-H. \& He Q.-J. 2015. Taxonomic review of the ponerine ant genus Leptogenys Roger, 1861 (Hymenoptera: Formicidae) with a key to the Oriental species. Myrmecological News 21: 137-161.

Manuscript received: 18 July 2019

Manuscript accepted: 4 October 2019

Published on: 13 December 2019

Topic editor: Gavin Broad

Desk editor: Pepe Fernández

Printed versions of all papers are also deposited in the libraries of the institutes that are members of the EJT consortium: Muséum national d'histoire naturelle, Paris, France; Meise Botanic Garden, Belgium; Royal Museum for Central Africa, Tervuren, Belgium; Royal Belgian Institute of Natural Sciences, Brussels, Belgium; Natural History Museum of Denmark, Copenhagen, Denmark; Naturalis Biodiversity Center, Leiden, the Netherlands; Museo Nacional de Ciencias Naturales-CSIC, Madrid, Spain; Real Jardín Botánico de Madrid CSIC, Spain; Zoological Research Museum Alexander Koenig, Bonn, Germany; National Museum, Prague, Czech Republic. 